\title{
Rhetorical Devices as the Strategy of Conceptualizing the Leadership Identity in American Political Speech
}

\author{
Zulvy Alivia Hanim, Universitas Airlangga \\ Hana Puspa Sari Dewi, Universitas Airlangga
}

\begin{abstract}
Political leadership was conceptualized in interactional between politician and citizens through the sociolinguistics term. This article aims to investigate the use of rhetorical devices and how it applied in the political speech. Political speech is characterized by rich information related to the condition of the government which reflects the social condition in the society. Focusing on the use of metaphor, euphemism, the rule of three, parallelism and pronoun, this study will explore how certain aspect of communication are affected by rhetorical devices based on Jones and Peccei (2004) theory.Glenn Back's speech was selected as the subject of this study. This study usesa qualitative approach to create a depth explanation of the way the speaker uttered and implied the implicit meaning of rhetorical devices in the speech. The finding of this research is expected to provide the valuable insight of rhetorical speech within the discourse approach.
\end{abstract}

Keywords: leadership; political speech; rhetoric

\section{Introduction}

In political discourse, politician employed many strategies to persuade people. According to Hague et. al (1998, in Chilton, 2004:4), defines politics as the involvement of reconciling differences through discussion and persuasion in which the communication is centralized in the political field. Campaign, commercials, posters, and mass media, are mediated them to communicate with the society. Those media needs the language to gain the effect of legitimacy and the authority through the language used recognized as the intrinsic aspect of the politics. Relation to language and politics, Fetzer and Bull (2012) asserted that it is true that politics is a form of the professional and media discourse not just in form of the text and talk. As the consequence, the study of communicative intent in the political behavior brings the language use become the significant part constitute in the politics.

In the political frameworks, politician brings the discourse identity in the leadership concept. The successful politicians are "do leadership in context" (Fetzer \& Bull, 2012). In this case, a politician should know how to behave such as listening to the reason, not being arrogant or selfish, and acting in a decisive and principled manner. To this leadership behavior, a politician used language to explore the quality of leadership in any political situation. Therefore, political speech is one of the media to attain the leadership identity from the way the politician as the leader who used the language to interact and communicate with the citizens.

In relation to the topic, Fetzer and Bull (2012) has examined the 15 British political speeches delivered at annual party-political conferences presented by three major political parties, conservative, labor, liberal democrat. In their article, sociopragmatics methodology was generated. Combining corpus linguistics and social psychology, this previous study attempt to see the competence and the responsiveness generated in the speech. As a result, they found that politician may display competence by presenting her/himself as the principled and display responsiveness by presenting her/himself as caring and has the emotional balanced. Furthermore, they found the prediction of a quality for leadership, such as being charismatic, responsive, competent, incompetent or arrogant.

Another research was conducted by Liu and Lei (2018) who examined the sentiments and discourse theme and also the strategies used in Hillary Clinton's and Donald Trump's speeches during the 2015 presidential election. This study used the machine-based automatic analyses to obtain the data. As the result, this study revealed that Trump's speeches were found 
significantly more negative than Clinton's. Despite the differences in methodology, these study provided the interesting finding on the use of language that represented the way the leader performs their leadership identity

In term of research focus, this study employed the speech as the data analysis because speech builds the communicative way to persuade people. One of the techniques that commonly used is the rhetorical device.The rhetorical or stylistic device is a technique where the speaker persuades the listeners to consider a topic by using the speaker's perspective and it can be used to generate, encourage and evoke listeners' emotion (John \& Peccei, 2004; Thomas et al., 2004). As it's widely used in the politics, particularly in the campaign, it will be interesting to know how rhetorical device used in other political events such as a political conference. Hence, this study is conducted.

The data will be taken from Glenn Beck's speech in The Conservative Political Action Conference (CPAC). CPAC is chosen as the data since it is a routine political conference held annually by political leaders of the conservative movement (www.cpac.conservative.org) while Glenn Beck is chosen because he is widely known for his political contribution for the conservative, political antics and bold criticism in conspiracy theories and political figures. This study aimed to know how rhetorical devices constructed by Glenn Beck's speech in The Conservative Political Action Conference (CPAC).

\section{Literature Review}

Jones and Peccei (2004, in Thomas et al., 2004) stated that rhetorical devices contain metaphor, euphemism, the rule of three, parallelism, and pronoun. Basically, a metaphor used for comparing two concepts. In politic discourse, the personification that is a special type of metaphor is frequently used to referring countries, for example, Germany is the bully in the playground'. By using a metaphor, the politicians can make the abstract concept more concrete so that they can be easily understood and the audience will not be boring.

Euphemism is word or phrase used to avoid the unpleasant or offensive word, for example, the use of the word correctional facility instead of jail. The euphemism used in politic discourse to avoid unpleasant words or negative impression to the audience. The rule of three or three-part statement used to convince the audience and is a powerful structure that politicians used to underline the important statements, for example, the politicians can repeat a word for three times such as unity, unity, unity.

Parallelism is a device used to express several ideas by using similar structures. It used by politicians to draw attention to a particular part of their message and emphasize it by using symmetry and rhythm to make it more memorable, for example, we shall fight, we shall defend, we shall never surrender. The last device is pronoun used by politicians to refer to themselves or their audience by using the word we for the relatively controversial speech where it is unclear whom we refer to and $I$ when they want to claim positive achievement. The switch of the pronoun can bring the audience together and encourage them to identify with the emotions felt by the politicians.

Beside rhetorical device, political language also shows the leadership of the politicians. Leadership is about getting people to want to do things. It is about shapingbeliefs, desires, priorities and achieving influence, not securingcompliance (Haslam, Reicher, \& Platow, 2011).Haslam et al(2011)stated that there are 4 principles of the effective leadership. First, the leaders must be seen as "one of us"or they need to be seen as an in-group prototype. Second, the leaders must be seen to "do it for us" where they are seen to promote the interests of the ingroup that make the followers are willing to do a task that helps the leader's vision into reality. Third, the leader must "craft a sense of us" that are shaping the understanding of "who we are". The leader's success lies in representing theirprojects and proposals as reflecting the norms, values, and priorities of thegroup.Fourth, the leaders must "make us matter". The point of leadership is to take the ideas, values, and priorities of the group and embed them in reality (Haslam et al., 2011). 


\section{Method}

Qualitative approach asserts as the method of this study aimed to give explorative information on howrhetorical devices constructed by Glenn Beck's speech in The Conservative Political Action Conference (CPAC). In detail, the qualitative approach that used is the qualitative approach with case study method. Case study method is the intensive, in-depth study of a specific individual or specific context or situation (Murray \& Beglar, 2009).

In this study, Glenn Beck's speech in The Conservative Political Action Conference (CPAC, 2016) becomes the main data analysis. As the conservative, Glenn Was Back known as the political commentators who give many distributions to the political issue in America. The speech was taken as the object since many viewers reacted to appreciate his speech that could be seen from 81.000 viewers watched his speech. However, the speech was downloaded and transcribed then analyzed by using rhetorical devices.

\section{Discussion}

As mention above, we ran fiverhetorical devices that produce thespeech. The rhetorical devices found in Glenn Beck's speech in The Conservative Political Action Conference (CPAC, 2016)aremetaphor, euphemism, the rule of three, parallelism, and pronoun. Each rhetorical device will be discussed as follows:

\subsubsection{Metaphor}

There are 4 Metaphor found in Glenn Beck's speech (CPAC, 2016) and will be discussed as follows:

1. The Founders don't cite any other reason in the Declaration. The Declaration doesn't say "To ensure there is a chicken in every pot."

The first data above, Glenn saida chicken in every pot is part of Herbert Hoover's statement that if he won, there would be a chicken in every pot and a car in every garage or he wants to ensure that everybody has the better quality of life.

2. It was The Constitution. Our principals. Equal justice. Our Golden Ticket

The second data of the metaphor expression indentified fromGolden Ticketmean the golden chance that can be used as a way to reach the goal.

3. Wonka says, "So shines a good deed in a weary world."

The third data aboveprovidesGood deed whose meaning a metaphor of goodness and $A$ weary world whose meaning a personification that including to special metaphor. The world explained as weary: tired of the crime and finally, goodness can shine in it.

4. They can't have us believe we're individuals. Instead, we are the possessions of the state, to be used to create a better world. And because they believe we aren't capable of creating this world on our own, we must be forced to live as we are told so the elites can create this world for us. And in the end, those who call themselves our saviors pull out guns and make us slaves. To them, Mao is right: you don't have power! To them, power comes from the barrel of a gun.

The fourth data above, the researchers highlighted the word "elites" that refer to the higher level in the society, so then they have the right to organize and regulate the social condition. Glenn used metaphor to soften the statement on the people who have power. It was supported by the last statement that power lies on the government decision in using the gun to a war in giving the solution of every problem.

\subsubsection{Euphemism}

The second rhetorical device is a euphemism. Political actors tend to avoid words or expressions that may have unpleasant associations in order not to give a negative impression to their audiences.

We steal the future from the young to allow for our own prosperity today. But we need cleaner air, right? 
From the data above, Glenn employed two rhetorical devices, those are euphemism and metaphor. In the first sentence, We steal the future from the youngdoes not mean that the audience should really steal the future from the young in the negative ways but Glenn invited the audience to step forward in reaching the successful for the future. The rhetorical device found in this datum is the statement of metaphor, such as Clearer air means better future that we need for the young generation.

\subsubsection{The rule of three}

The third rhetorical device is the rule of three. The rule of three sounds particularly complete, satisfying and convincing. It is also known as the use of the 'three-part statement'. For instance:

We hold these truths to be self-evident, that all men are created equal, that they are endowed by their Creator with certain unalienable Rights that among these are Life, Liberty and the pursuit of Happiness.

The wordsLife, Liberty and the pursuit of Happinessare noun that all of thewords are the purpose of everybody's life. People commonly need these three elements in their life. Therefore, the speaker intended to remind the audience that the real goal of life is consists of these three statements.

\subsubsection{Parallelism}

There is 8 parallelisms found in Glenn Beck's speech used foremphasizing particular sentences by using symmetry and rhythm to make it more memorable, for example in the sentence they didn't elect to have a king. They didn't choose a path of forced cooperation like socialism or communism, and they didn't place power in the hands of the wealthy or the elite.

\subsubsection{Pronoun} as follows:

There are 5 Pronoun found in Glenn Beck's speech (CPAC, 2016) and will be discussed

1. Pronoun $W e$

In his speech, Glenn Beck uses pronoun we in the 10 sentences that show controversial speech where the sentences have negative meaning and it is unclear whom we refer toas for examples: (1) We're all guilty. We're enslaving our children for our own comfort. (2) We steal the future from the young to allow for our own prosperity today.

Besides, from the context it is found that Glenn Beck also uses pronoun we in the 14 sentences that refer to Glenn Beck and the audience where the sentences have a positive meaning and stated their need, for examples: (1) We are capable of working with others in voluntary cooperation for the common good. (2) We are also capable of competing with others for resources and achievement. (3) We need only raise our voices,... and refuse forever to surrender our way of life. The use of pronoun we that refers to Glenn Beck and the audience can bring the audience together and encourage them to identify with the emotions felt by Glenn Beck.

2. Pronoun $I$

There are 5 pronouns $I$ in Glenn Beck's speech that show positive meaning, such as delivering his idea and giving complement the audience as follows:

- Tonight, I want to speak to you about ideas that will seem, perhaps, less practical, less ... tactical.

- I tell you that you are the most powerful being ever created.

The use of pronoun I refers to the involvement of the speaker to entail the listener's interaction. The pronoun I gives the authority of the speaker to give any statements.

\subsection{Glenn Beck's speech reflect the effective leadership principles}

In CPAC 2016, Glenn Beck's speech reflects the effective leadership principles as stated by as follows: 


\section{First principle}

Glenn Beck fulfills the first principle by using the pronoun we thatrefers to himand the audience/the followers, so that he can be seen as one of hisaudience/followers. Besides, Glenn Beck also states that he is part of the group as in the sentence I am so honored to be among you at this conference. Our movement isn't about Parties, it's about each other.

2. Second principle

Glenn Beck fulfills the second principle bystating that he will do the task in order to reach their goal and persuade his audience/followers to do it together as in the sentence As conservatives, it is our duty to bear that responsibility for this generation and the next. Our time is now. It falls to us, to follow our God-given principals.

3. Third principle

Glenn Beck fulfills the third principle by statedhis audience/followers potential such as in the sentenceyou're capable of choosingright to wrong, morality from immoralityand I tell you that you are the most powerful being ever created.

4. Fourth principle

GlennBeckfulfillsthethirdprincipleby representing their ideas and goals in his speech, for examplein the sentence We need only raise our voices, honor our pledge to one another and refuse forever to surrender our way of life.

\section{Conclusion}

In political discourse, politician employed many strategies to persuade people by using politicallanguage. One of the techniques that commonly used in the political language is the rhetoricaldevice. The rhetorical or stylistic device is a technique where the speaker persuades the listenersto consider a topic by using the speaker's perspective and it can be used to generate, encourageand evoke listeners' emotion. Focusing on the use of metaphor, euphemism, the rule of three,parallelism and pronoun, this study will explore how certain aspect of communication areaffected by rhetorical devices based on Jones and Peccei (2004) theory. Glenn Back's speech inCPAC 2016 was selected as the subject of this study.

In Glenn Beck's speech found 4 metaphor, 1 euphemism, 5 therule of three, 8 parallelism and 4 pronouns. The most used device is parallelism that is used toemphasizing particular sentences by using symmetry and rhythm to make it more memorable.Glenn Beck's speech also reflects the 4 effective leadership principles as stated by Haslam et. al (2011). In his speech, Glenn Beck fulfills the criteria of all of the principleby using the pronoun we that refers to himand the audience/the followers so that he can be seen that the leader become the part of the audience or the society (first principle), stating that he will do the task in order to reachtheir goal and persuade his audience/citizens to do the task together (second principle), stating hisaudience/followers potential (third principle) and representing their ideas and goals in hisspeech (fourth principle). However, by fulfilling the criteria of leadership principle, the leader performs his/her leadership identity through the political discourse.

\section{References}

Chilton, P. 2004. Analysing Political Discourse: Theory and Practice. New York, London: Routledge.

Fetzer, A., \& Bull, P. 2012. Doing leadership in political speech: Semantic processes and pragmatic inferences. Discourse \& Society, 23(2), 127-144. Available at https://doi.org/10.1177/0957926511431510

Haslam, S. A., Reicher, S. D., \& Platow, M. J. 2011. The new psychology of leadership: identity, influence and power. Hove: Psychology Press.

King, N. A. S., \& Milanzi, M. C. n.d. The Role of Political Leaders in Enhancing Peace and Tranquility: Thinking Big. International Journal of Managerial Studies and Research, 8.

Lord, R. G., \& Brown, D. J. 2004. Leadership processes and follower self-identity. Mahwah, N. $\mathrm{J}$ : Lawrence Erlbaum. 
Murray, N., \& Beglar, D. 2009. Inside track: writing dissertations and theses. Harlow, England; New York: Pearson Longman.

Thomas, L., Wareing, S., Singh, I., Peccei, J. S., Thornborrow, J., \& Jones, J. 2004. Language, Society and Power: An Introduction, Second Edition (second). London and New York: Routledge. 